\title{
Frankenstein and the Politics of Vulnerability
}

Sara Wasson, Lancaster University

'I am an unfortunate and deserted creature ... I have no relation or friend upon earth' (Shelley 1818: 90). At the heart of Frankenstein lies the Creature's imploring cry for connection. The novel offers a passionate condemnation of individual ambition and neglect of a person dependent on oneself. Framed in that way, the book can be read as reinforcing a binary between dependency and agency. Yet from another perspective, the book can be read as complicating that very binary in ways that are of increasing interest to disability studies, political theory and feminist theory. Such rethinking is politically urgent, both to reduce current stigmatisation and state neglect (Fineman 2008; Satz 2008; Kittay 2015), and to support creative strategies of resistance that move beyond paternalism (Butler 2016; Butler, Gambetti and Sabsay, 2016). Two hundred years after it was first published, Frankenstein can be read as constructing a complex picture of vulnerability as simultaneously ontological and situated, both intrinsic to embodiment and induced by specific social relations.

Approaching Frankenstein from the perspective of feminist ethics of care (Gilligan 1982; Noddings, 1984), a reader rightly notes the pathos of the creature's abandonment and Victor's profound transgression in failing to meet his duties of care. Yet these approaches still risk entrenching an active/passive division between those configured as vulnerable or dependent, and those who care (Shildrick 2002: 76-7). On the one hand, it is necessary to recognise that dependency and vulnerability are universal, in order for necessary reform to state support and maladaptive environments (Fineman 2008; Kafer 2013; Satz 2008; Kittay 2015). All humans are dependent on food, shelter, infrastructure and social connection, and are vulnerable to material, social and environmental threat. On the other hand, it is also true 
that certain groups are rendered more vulnerable than others by, for example, structural violence. Rather than seeing vulnerability as simply universal, or simply a property of certain groups, it is more accurate to think of all agency as enabled by particular dependencies. This insight is emerging within numerous fields, including new materialisms (Bennett 2010), disability studies' political-relational models (Kafer 2013), and retheorisations of resistance (Butler 2016). The ability to act emerges within networks of force, discourse, social networks, and materials inorganic and organic.

Throughout Frankenstein's nested narrations, we repeatedly see vulnerability understood in relational and contingent terms. Victor is repeatedly reduced to profound helplessness, dependent on Walton and Clerval for rescue and care. Yet unlike the creature, Victor has an apparatus of support, both social and economic. Furthermore, the creature is interdependent (Fine and Glendinning 2005), in that he in turn repeatedly helps the de Lacey family. Finally, it has been traditional to see the creature's vulnerability as an embodiment of pathos. Yet we can also frame his defiant central speech in terms of bravery and the potential for transformative action, vulnerability enabling resistance (Butler, Gambetti and Sabsay 2016: 7). In his wounds, his yearning, and his acute knowledge of the indispensability of interrelationship, the creature confirms vulnerability as both inevitable and relational.

\section{References}

Bennett, Jane. Vibrant Matter: A Political Ecology of Things. Durham: Duke University Press, 2010.

Butler, Judith, Zeynep Gambetti and Leticia Sabsay. "Introduction”. Vulnerability in Resistance, ed. by Judith Butler, Zeynep Gambetti and Leticia Sabsay. Durham: Duke University Press, 2016, pp. 1-11 
Butler, Judith. "Rethinking Vulnerability and Resistance." Vulnerability in Resistance, ed. by Judith Butler, Zeynep Gambetti and Leticia Sabsay. Durham: Duke University Press, 2016, pp. 12-27.

Fine, Michael and Caroline Glendinning. “Dependence, Independence or Interdependence?" Ageing and Society, vol. 25, no. 4, 2005, pp. 601-21.

Fineman, Martha Albertson. "The Vulnerable Subject." Yale Journal of Law and Feminism, vol. 20, no.1, 2008, p.1-23.

Fraser, Nancy and Linda Gordon. “A Genealogy of Dependency.” Signs, vol. 19, no. 2, 1994, pp. 309-336.

Gilligan, Carol, In a Different Voice. Cambridge, MA: Harvard University Press, 2016 [1982].

Kafer, Alison. Feminist, Queer, Crip. Bloomington: Indiana University Press, 2013.

Kirkland, Anna. "What Next?" Against Health, ed. by Jonathan Metzl and Anna Kirkland. New York: NYU Press, 2010, pp. 195-204.

Kittay, Eva Feder. "Dependency." Keywords for Disability Studies, ed. by Rachel Adams, David Serlin and Benjamin Reiss. New York: NYU Press, 2015, pp. 54-58.

Noddings, Nel, Caring. Berkeley: University of California Press, 1984.

Satz, Ani. "Disability, Vulnerability and the Limits of Antidiscrimination." Washington Law Review, vol. 83, no. 4, 2008, pp. 513-68.

Shelley, Mary. Frankenstein. New York: Norton, [1818] 1996.

Shildrick, Margrit. Embodying the Monster. London: Sage, 2002. 